\title{
Effects of Atmospheric Composition on Respiratory Behavior, Weight Loss, and Appearance of Camembert-Type Cheeses During Chamber Ripening
}

\author{
D. Picque ${ }^{\star 1}$ M.-N. Leclercq-Perlat, and G. Corrieu \\ Unité Mixte de Recherche Génie et Microbiologie des Procédés Alimentaires, Institut National de la Recherche Agronomique, \\ F 78850 Thiverval Grignon, France
}

\begin{abstract}
Respiratory activity, weight loss, and appearance of Camembert-type cheeses were studied during chamber ripening in relation to atmospheric composition. Cheese ripening was carried out in chambers under continuously renewed, periodically renewed, or nonrenewed gaseous atmospheres or under a $\mathrm{CO}_{2}$ concentration kept constant at either 2 or $6 \%$ throughout the chamberripening process. It was found that overall atmospheric composition, and especially $\mathrm{CO}_{2}$ concentration, of the ripening chamber affected respiratory activity. When $\mathrm{CO}_{2}$ was maintained at either 2 or $6 \%, \mathrm{O}_{2}$ consumption and $\mathrm{CO}_{2}$ production (and their kinetics) were higher compared with ripening trials carried out without regulating $\mathrm{CO}_{2}$ concentration over time. Global weight loss was maximal under continuously renewed atmospheric conditions. In this case, the airflow increased exchanges between cheeses and the atmosphere. The ratio between water evaporation and $\mathrm{CO}_{2}$ release also depended on atmospheric composition, especially $\mathrm{CO}_{2}$ concentration. The thickening of the creamy underrind increased more quickly when $\mathrm{CO}_{2}$ was present in the chamber from the beginning of the ripening process. However, $\mathrm{CO}_{2}$ concentrations higher than $2 \%$ negatively influenced the appearance of the cheeses.
\end{abstract}

Key words: cheese ripening, atmospheric composition, respiratory activity, weight loss and appearance

\section{INTRODUCTION}

It is during ripening that cheese must acquire its texture, flavor, and organoleptic properties. Biochemical changes, such as lactose, lactic acid, and citrate metabolisms, as well as proteolysis and lipolysis, are due to different enzymes that are initially present in milk or synthesized by microorganisms involved in ripening and to intact, metabolically active cells. The

Received July 19, 2005.

Accepted January 31, 2006.

${ }^{1}$ Corresponding author: picque@grignon.inra.fr growth of microorganisms associated with enzymatic activities and responsible for ripening depends on many factors (Ramet, 1997) especially those related to cheese composition ( $\mathrm{pH}$, redox potential, and water activity) and environmental conditions (temperature, relative humidity, airflow rate, and atmospheric composition).

The influences of cheese $\mathrm{pH}$ and water activity $\left(\mathbf{a}_{\mathbf{w}}\right)$ on microbial growth and enzyme activities during ripening have been described in depth. Their values have been adjusted depending on each type of cheese (Ramet, 1997), and they have been related to microflora composition.

Among the environmental factors, ripening temperature is considered the major external parameter due to its accelerating or inhibitory effects on the rate of many changes during ripening. For instance, an increase of temperature from 0 to $15^{\circ} \mathrm{C}$ raises the level of degradation of $\alpha_{\mathrm{S} 1}$-casein as well as the levels of soluble nitrogen compounds at $\mathrm{pH} 4.4$ and phosphotungstic acid soluble nitrogen compounds. It also changes apparent viscosity and functionality properties of Mozzarella cheeses (Feeney et al., 2001; Guinee et al., 2001). Al-O Taibi and Wilbey (2004) confirmed the effects of temperature on proteolysis and texture of white-salted cheeses during ripening. However, the required accelerating effect has to be controlled because temperatures that are too high can lead to synthesis of undesirable products that negatively modify organoleptic properties of the cheese (Kujawski et al., 2003).

In the ripening chamber, relative humidity $(\mathbf{R H})$ of the atmosphere is controlled according to the type of cheese. Relative humidity affects rind $\mathrm{a}_{\mathrm{w}}$ and water losses (Weissenfluh and Puhan, 1987; Macedo et al., 1997; Simal et al., 2001). A decrease in RH from 98 to $95 \%$ has been shown to increase water losses 2.5-fold (Mirade et al., 2004). Airflow rate has also been shown to have an effect on water evaporation (Weissenfluh and Puhan, 1987). Weight losses have been known to increase 6 times when air velocity changes from 0 to $0.5 \mathrm{~m} / \mathrm{s}$ (Mirade et al., 2004). Airflow rate also changes atmospheric composition, which acts on ripening phenomena. However, little data have been published 
about this, explaining, in part, why regulation of atmospheric composition of ripening chambers remains empirical.

Oxygen consumption has been correlated to $\mathrm{CO}_{2}$ production during the ripening of cooked pressed cheeses (Blanc et al., 1983) and soft mold-ripening cheeses (Kiermeier and Wolfseder, 1972; Roger et al., 1998). Doyon et al. (1997) found that $\mathrm{O}_{2}$ concentrations between 10 and $40 \%$ did not change growth of Penicillium camemberti, but $\mathrm{CO}_{2}$ concentrations between 10 and $30 \%$ (with at least $12 \% \mathrm{O}_{2}$ ) were inhibitory; the higher the concentration of $\mathrm{CO}_{2}$, the slower the observed growth. Roger et al. (1998) showed that changes in partial pressures of $\mathrm{O}_{2}$ and $\mathrm{CO}_{2}$ affected the respiration rate of $P$. camemberti. Respiration rate decreased when the oxygen partial pressure was reduced to below 5,000 $\mathrm{Pa}$ (about $1 \% \mathrm{O}_{2}$ ).

Ammonia also has an impact on ripening. Produced by catabolism of amino acids or introduced by cheese makers, ammonia contributes to growth of acid-sensitive flora (coryneform bacteria, Micrococcaceae) by neutralization of the cheese surface area. In soft cheese making, an ammonia atmosphere has a significant effect on cheese ripening, increasing $\mathrm{pH}$ earlier than usual, reducing Penicillium growth, and lowering the level of proteolysis and bitterness (Vassal and Gripon, 1984).

The aim of this study was to focus on the evolution of $\mathrm{O}_{2}$ and $\mathrm{CO}_{2}$ during cheese ripening performed under various conditions of airflow and atmospheric compositions. We evaluated the effects on respiratory rate, weight loss, and ripening rate; the latter was estimated on line by changes in the thickness of the creamy underrind and by the appearance of the cheeses.

\section{MATERIALS AND METHODS}

\section{Cheese Production and Ripening}

Soft cheeses (Camembert type) were manufactured in a sterile environment as previously described (LeclercqPerlat et al., 2004). Four microorganisms (Kluyveromyces lactis, Geotrichum candidum, Penicillium camemberti, and Brevibacterium aurantiacum) were used as ripening strains to inoculate the milk. Forty-five cheeses per production run were manufactured, each weighing $360 \pm 20 \mathrm{~g}$ on $\mathrm{d} 1$. After drainage, the cheeses were aseptically transferred to a sterile ripening chamber $\left(\right.$ volume $=0.99 \mathrm{~m}^{3}$, regulated at $13^{\circ} \mathrm{C}$ ); this point was designated initial time (d 0 ).

After $24 \mathrm{~h}$ at $85 \pm 2 \% \mathrm{RH}$ and $13^{\circ} \mathrm{C}$, the cheeses were kept at $95 \pm 2 \% \mathrm{RH}$. They remained under different atmospheric conditions from $d 0$ to 16 (wrapping). The cheeses were turned over on d 5 .
Five different controlled atmospheres were set up for the chamber ripening: 1) continuously renewed atmosphere (CRA; flow rate $=2 \mathrm{~m}^{3} / \mathrm{h}$, renewal rate $=2$ ), a composition similar to air; the renewed rate was calculated by flow rate/volume of the ripening room ratio; 2) periodically renewed atmosphere (PRA); the ripening room was kept closed but, if necessary, every $24 \mathrm{~h}$ and one time $48 \mathrm{~h}$ (after the weekend), the $\mathrm{CO}_{2}$ level was decreased to $2 \%$ by air injection; 3 ) no renewed atmosphere (NRA); the ripening room was sealed during ripening; 4) the level of $\mathrm{CO}_{2}$ was kept constant at $2 \%$ from d 0 to $16\left(\mathbf{2 C O}_{2}\right)$; and 5) the level of $\mathrm{CO}_{2}$ was kept constant at $6 \%$ from d 0 to $16\left(\mathbf{6 C O}_{2}\right)$. All runs were duplicated.

\section{Monitoring Cheese Ripening}

For each run, $\mathrm{CO}_{2}$ (infrared analyzer Iridium 100, City Technology, Portsmouth, UK) and $\mathrm{O}_{2}$ (electrochemical sensor CiTycel, City Technology) concentrations as well as RH (Hygroclips, Rotronic, Croissy Beauborg, France) were measured on-line using an external sampling gas loop connected to the ripening room. Moreover, a representative cheese was continuously weighed using an electronic balance (Precisa, XB620C, precision \pm 0.01 g; Precisa, Poissy, France).

A homeade software program (CRIC software, GMPA, Thierval Grignon, France) running on a PC was used to record the sensor signals, process the data, and monitor the $\mathrm{CO}_{2}$ level by $\mathrm{CO}_{2}$ or air injection.

\section{Appearance of Cheeses}

The thickening of the creamy underrind provides information about the ripening level because the underrind increases as a function of proteolysis and lipolysis progress (Bonaïti et al., 2004). The thickness of the cheese underrind was determined using 6 points on each face of the cheese, and an arithmetic average of those 12 measurements was calculated.

On d 12, 3 cheese evaluators graded 4 sensory properties of the cheeses as defined by Olarte et al. (2001) and Perrot et al. (2004): 1) color, a visual evaluation varying from white to cream colored; 2) coating, based on density and uniformity of mycelia (low, moderate, high); 3) visual and tactile moisture of the surface (dry, low, high); and 4) form, depending on the overall external shape of the cheese.

\section{RESULTS}

\section{$\mathrm{O}_{2}$ Consumption and $\mathrm{CO}_{2}$ Production}

Concentrations of $\mathrm{CO}_{2}$ and $\mathrm{O}_{2}$ measured in the ripening room as a function of ripening time during the differ- 

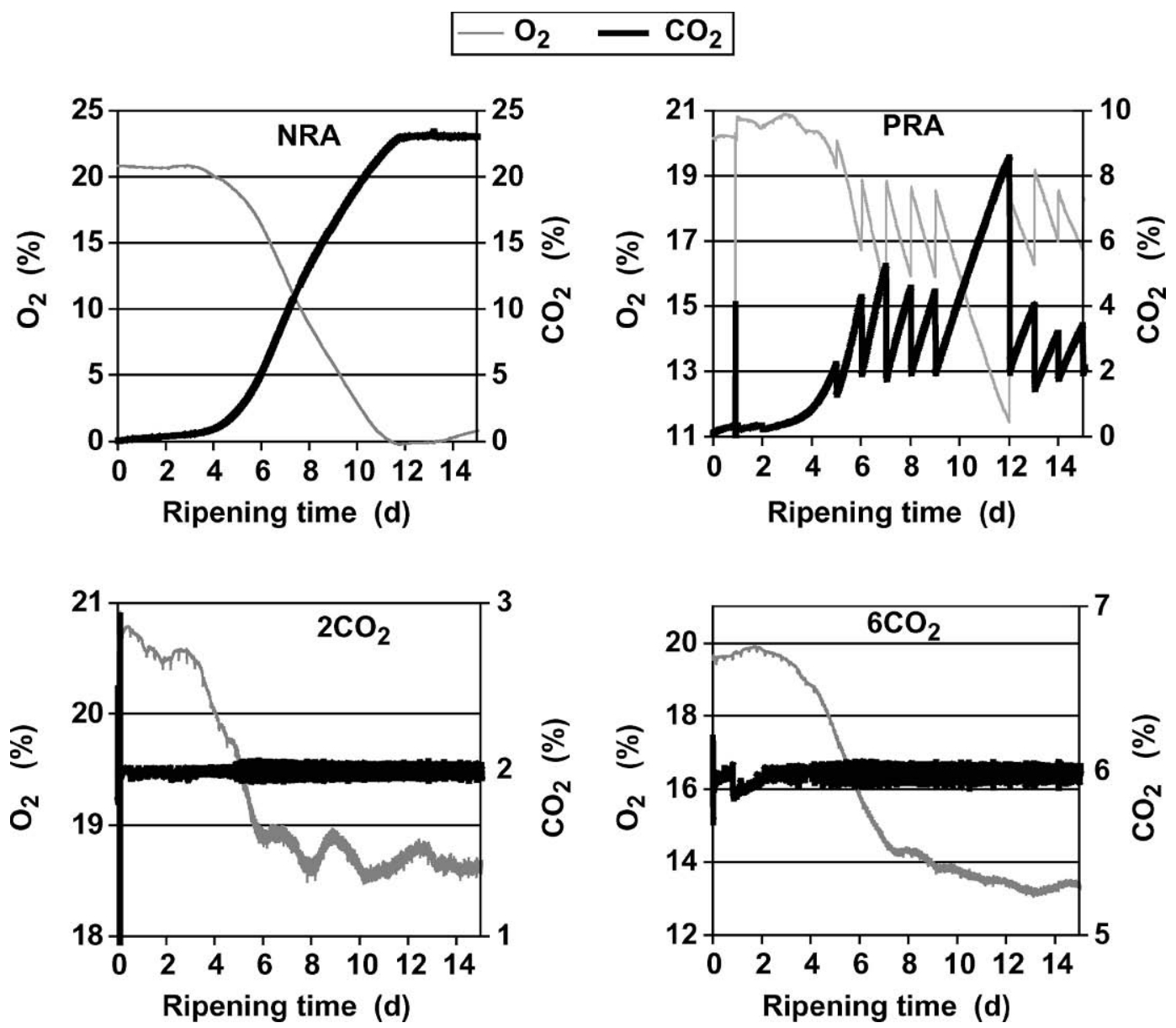

Figure 1. Changes in $\mathrm{O}_{2}$ and $\mathrm{CO}_{2}$ concentrations observed in the ripening room as a function of ripening time. NRA = no renewed atmosphere; PRA = periodically renewed atmosphere; $2 \mathrm{CO}_{2}, 6 \mathrm{CO}_{2}=$ regulation of $\mathrm{CO}_{2}$ concentration at 2 and $6 \%$, respectively.

ent trials are presented in Figure 1. During the first 3 $\mathrm{d}$, the $\mathrm{O}_{2}$ and $\mathrm{CO}_{2}$ concentrations did not significantly change. After d 3, their evolutions vs. ripening time were very different according to the atmospheric conditions. Under CRA, the changes in $\mathrm{CO}_{2}$ and $\mathrm{O}_{2}$ concentrations, in relation to time, were negligible. No significant dynamics were recorded (data not shown). The composition of the ripening atmosphere was similar to that of air due to the high air renewal rate. In the sealed ripening chamber (NRA), the atmospheric composition changed drastically between $\mathrm{d} 4$ and 12 . Oxygen completely disappeared and $\mathrm{CO}_{2}$ concentration increased up to $23 \%$ (Figure 1). From d 12 to $16, \mathrm{CO}_{2}$ concentration remained constant at $23 \%$. Under PRA conditions, on $\mathrm{d} 4$, the concentrations of $\mathrm{O}_{2}$ and $\mathrm{CO}_{2}$ fluctuated between 19 and $16 \%$ (down to $11.5 \%$ on d 12 ) and between 2 and $5 \%$ (up to $8.5 \%$ on d 12), respectively (Figure 1).

The ripening trial carried out under the $2 \mathrm{CO}_{2}$ conditions presented the same dynamics, in relation to time, as that carried out under $6 \mathrm{CO}_{2}$ conditions. However,
$\mathrm{O}_{2}$ concentration reached 18.5 and $13.5 \%$ in the $2 \mathrm{CO}_{2}$ and $6 \mathrm{CO}_{2}$ chambers, respectively (Figure 1).

\section{Respiratory Activity of Cheeses During Ripening}

Using $\mathrm{O}_{2}$ and $\mathrm{CO}_{2}$ concentrations measured in the ripening chamber, it was possible to calculate, as a function of ripening time, 1 ) the cheese respiration rate characterized by the $\mathrm{CO}_{2}$ production rate, and 2) the total amount of $\mathrm{CO}_{2}$ produced and of $\mathrm{O}_{2}$ consumed during ripening. The corresponding results obtained for 4 controlled atmospheres (NRA, PRA, $2 \mathrm{CO}_{2}$, and $6 \mathrm{CO}_{2}$ ) are shown in Figure 2 and Table 1.

In the NRA, the maximum respiration rates $(0.057$ $\pm 0.009 \mathrm{~mol} / \mathrm{m}^{2}$ per $\mathrm{h}$ ) were observed on $\mathrm{d} 7$ (Figure 2). On $\mathrm{d} 11$, the $\mathrm{O}_{2}$ of the chamber was totally consumed and the respiration rate fell to zero (Figure 2); $8.45 \mathrm{~mol}$ of $\mathrm{O}_{2}$ were replaced by $9.2 \mathrm{~mol}$ of $\mathrm{CO}_{2}$ for an average respiratory ratio of about $1.09 \pm 0.01$. Under PRA, the respiration rate increased rapidly from $d 3$ to 6 . On $d$ 


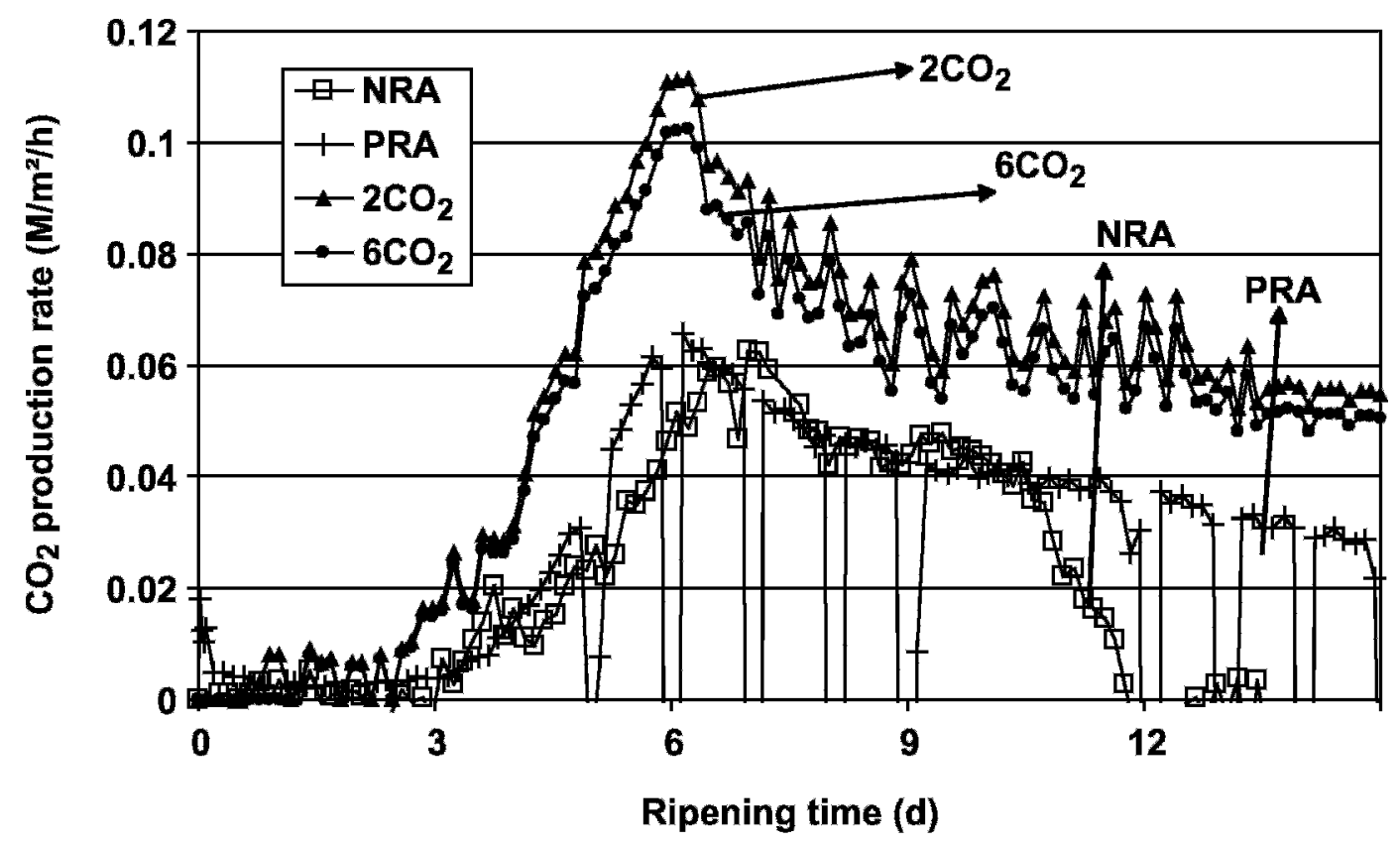

Figure 2. Production rate of $\mathrm{CO}_{2}$ as a function of ripening time for different atmospheric conditions. NRA = no renewed atmosphere; $\mathrm{PRA}=$ periodically renewed atmosphere; $2 \mathrm{CO}_{2}, 6 \mathrm{CO}_{2}=$ regulation of $\mathrm{CO}_{2}$ concentration at 2 and $6 \%$, respectively.

6 , the maximum rates were reached $(0.060 \pm 0.002 \mathrm{~mol} /$ $\mathrm{m}^{2}$ per $\mathrm{h}$ for $\mathrm{O}_{2}$ and $\mathrm{CO}_{2}$ ). Then, and until d 16 , a slow decrease to $0.03 \mathrm{~mol} / \mathrm{m}^{2}$ per h was observed (Figure 2). Total $\mathrm{O}_{2}$ consumption and the $\mathrm{CO}_{2}$ production were similar, close to $10 \mathrm{~mol} / \mathrm{m}^{2}$, and the average respiratory ratio was $0.94 \pm 0.03$ (Table 1 ).

When the ripening trials were performed under a constant $\mathrm{CO}_{2}$ concentration (either $2 \mathrm{CO}_{2}$ or $6 \mathrm{CO}_{2}$ ), respiratory activity began early (on $\mathrm{d} 2.5$ ) and reached the highest maximum values on $\mathrm{d} 6: 0.129 \pm 0.009 \mathrm{~mol}$ of $\mathrm{O}_{2} / \mathrm{m}^{2}$ per $\mathrm{h}$ and $0.115 \pm 0.005 \mathrm{~mol}$ of $\mathrm{CO}_{2} / \mathrm{m}^{2}$ per $\mathrm{h}$ for the trials performed under $2 \mathrm{CO}_{2} ; 0.10 \pm 0.01 \mathrm{~mol}$ of $\mathrm{O}_{2} / \mathrm{m}^{2}$ per $\mathrm{h}$ and $0.098 \pm 0.008 \mathrm{~mol}$ of $\mathrm{CO}_{2} / \mathrm{m}^{2}$ per $\mathrm{h}$ for the trials performed under $6 \mathrm{CO}_{2}$ (Figure 2). At the end of chamber ripening (d 16), the respiration rates were about $0.05 \mathrm{~mol} / \mathrm{m}^{2}$ per $\mathrm{h}$, close to the higher levels reached during the other runs (NRA and PRA). The average respiratory ratio did not differ significantly as a function of $\mathrm{CO}_{2}$ concentration. During the $2 \mathrm{CO}_{2}$ test, $20.98 \pm 0.36 \mathrm{~mol}$ of $\mathrm{O}_{2}$ were consumed and $20.09 \pm 0.48$ mol of $\mathrm{CO}_{2}$ were produced compared $17.45 \pm 0.45$ and $17.75 \pm 0.35$, respectively, during the $6 \mathrm{CO}_{2}$ tests (Table 1).

\section{Weight Loss of Cheese}

The recorded weight losses of cheeses vs. ripening time are shown in Figure 3. The weight loss dynamics can be divided into 3 phases: 1 ) The first phase (P1), characterized by a rapid linear loss, was observed during the first day of ripening; 2) the second phase (P2), characterized by a slower linear loss, was observed from d 2 to 4 (PRA, $2 \mathrm{CO}_{2}, 6 \mathrm{CO}_{2}$ ) or d 5 (CRA, NRA); and 3) the third phase (P3) did not appear perfectly linear and

Table 1. Total amount of $\mathrm{O}_{2}$ consumed, $\mathrm{CO}_{2}$ produced, maximum rate, and respiratory ratio characterizing cheese ripening for different gaseous atmospheric conditions ${ }^{1}$

\begin{tabular}{lcccc}
\hline & \multicolumn{3}{c}{ Atmospheric conditions } \\
\cline { 2 - 5 } & $\mathrm{NRA}$ & PRA & $2 \mathrm{CO}_{2}$ & $6 \mathrm{CO}_{2}$ \\
\hline $\mathrm{O}_{2}$ consumption, mol $/ \mathrm{m}^{2}$ & $8.45 \pm 0.40$ & $10.62 \pm 0.48$ & $20.98 \pm 0.36$ \\
$\mathrm{O}_{2}$ maximum consumption rate, $\mathrm{mol} / \mathrm{m}^{2}$ per $\mathrm{h}$ & $0.057 \pm 0.009$ & $0.060 \pm 0.002$ & $0.129 \pm 0.009$ & $0.100 \pm 0.45 \pm 0.010$ \\
$\mathrm{CO}_{2}$ production, mol/m ${ }^{2}$ & $9.20 \pm 0.40$ & $10.00 \pm 0.77$ & $20.09 \pm 0.48$ & $17.75 \pm 0.35$ \\
$\mathrm{CO}_{2}$ maximum production rate, $\mathrm{mol} / \mathrm{m}^{2}$ per $\mathrm{h}$ & $0.057 \pm 0.009$ & $0.060 \pm 0.002$ & $0.115 \pm 0.005$ & $0.098 \pm 0.008$ \\
Respiratory ratio & $1.09 \pm 0.01$ & $0.94 \pm 0.03$ & $0.96 \pm 0.04$ & $1.02 \pm 0.01$ \\
\hline
\end{tabular}

${ }^{1}$ Each value is the mean of the 2 runs, \pm standard deviation. NRA = No renewed atmosphere; PRA = periodically renewed atmosphere; $2 \mathrm{CO}_{2}, 6 \mathrm{CO}_{2}=$ regulation of $\mathrm{CO}_{2}$ concentration at 2 and $6 \%$, respectively. 


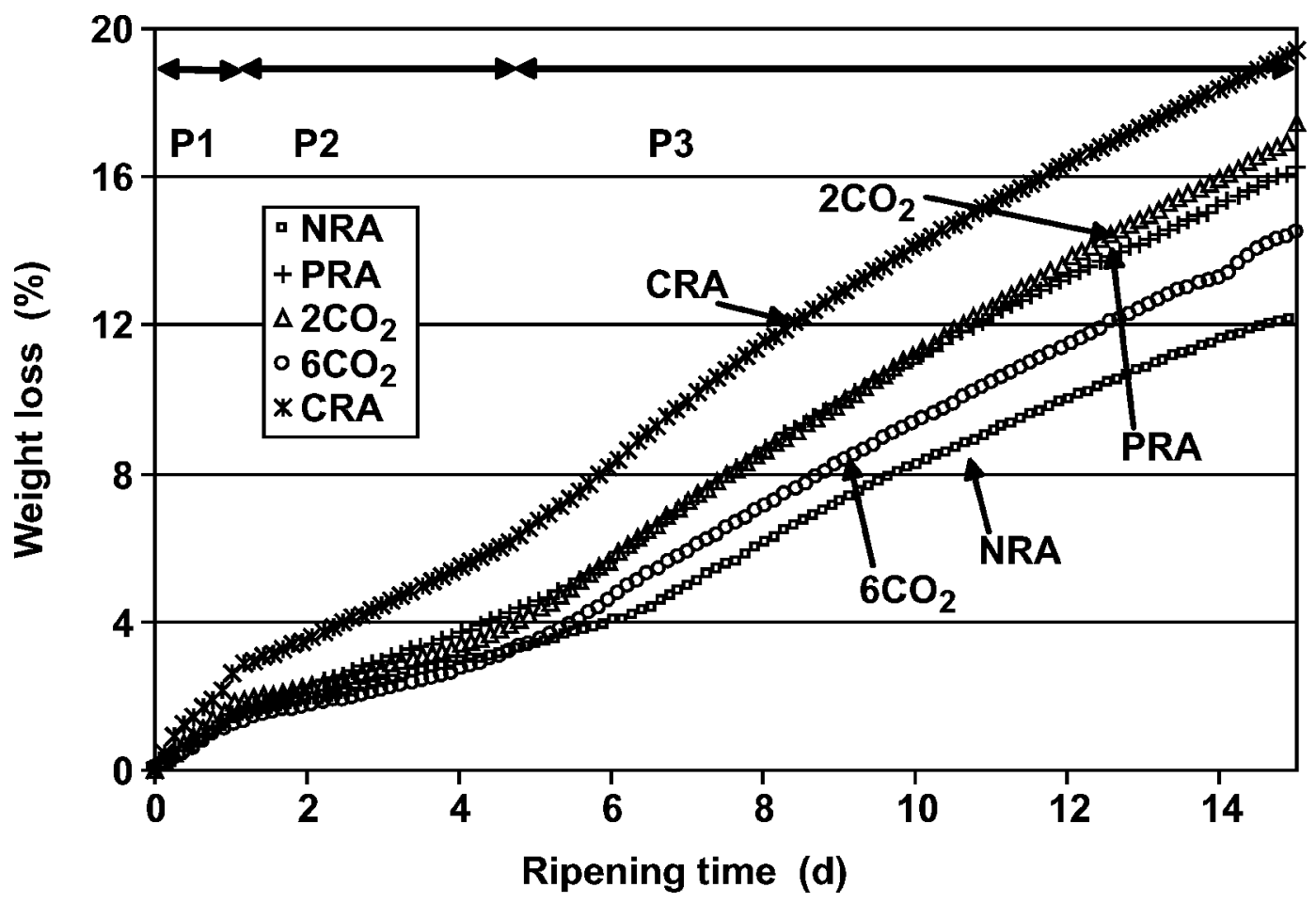

Figure 3. Weight losses of cheese vs. ripening time for 5 different atmospheric conditions. CRA = continuously renewed atmosphere; $\mathrm{NRA}=$ no renewed atmosphere; PRA = periodically renewed atmosphere; $2 \mathrm{CO}_{2}, 6 \mathrm{CO}_{2}=$ regulation of $\mathrm{CO}_{2}$ concentration at 2 and $6 \%$, respectively. Three phases (P1, P2, and P3) characterized the phenomena.

was observed from $\mathrm{d} 4$ or 5 up to the end of the process (d 16). Total weight losses and mean rates for each phase are presented in Figure 4.

Whatever the ripening atmospheric conditions, the highest rates of total weight losses due to $\mathrm{RH}$ set at $85 \%$ were measured during the first day (P1) of ripening. In $\mathrm{P} 1$, under CRA, the mean rate reached $2.25 \% / \mathrm{d}$. The mean rates observed for all the other atmospheric conditions were 1.24 to $1.71 \% / d$. During P2, the difference of weight loss rates between the runs was the same as the ones observed during P1 (Figure 4A). However, the mean rates obtained for $\mathrm{P} 2$ were about $60 \%$ lower than those obtained for P1.

For P3, under all ripening conditions, mean rates increased compared with P2. This increase was more significant for trials performed with regulated $\mathrm{CO}_{2}$ (at least $100 \%$ more) compared with the ones run with no regulation of $\mathrm{CO}_{2}$ (CRA, NRA; about $60 \%$ more). In this phase, the difference of mean rates between $\mathrm{PRA}, 2 \mathrm{CO}_{2}$, $6 \mathrm{CO}_{2}$, and CRA was under $10 \%$ (Figure 4). The cheese ripening in NRA showed a weight loss rate slower by at least $20 \%$.

Total losses reached after $15 \mathrm{~d}$ depended on the composition of the ripening atmosphere (Figure 3). They were lowest $(12.3 \pm 0.3 \%)$ when ripening was performed in an NRA chamber and highest $(19.4 \pm 0.03 \%)$ when it was carried out under CRA. These 2 levels represented 44 and $70 \mathrm{~g}$ of weight loss, respectively. For ripening trials with a constant $\mathrm{CO}_{2}$ concentration (either 2 or 6\%), or with PRA, weight loss values were included between these 2 extremes. Indeed, for these 3 trials, weight loss values represented: $14.5 \pm 0.05 \%$ for $6 \mathrm{CO}_{2}, 17.43 \pm 0.5 \%$ for $2 \mathrm{CO}_{2}$, and $16.2 \pm 0.2 \%$ for PRA chambers.

\section{Thickness of the Creamy Underrind and Appearance of the Cheeses}

Figure 5 shows the evolution of the thickness of the creamy underrind during chamber ripening for the different atmospheres. During the first $7 \mathrm{~d}$, there was no measurable underrind. Between $\mathrm{d} 7$ and 10, the creamy underrind thickness increased, reaching $1 \mathrm{~mm}$ for CRA, PRA, and NRA and $2 \mathrm{~mm}$ for $2 \mathrm{CO}_{2}$ and $6 \mathrm{CO}_{2}$. From d 10 to the end of ripening, the thickness remained constant for the NRA run, but increased very slowly for CRA and PRA runs (mean rate $=0.1 \mathrm{~mm} / \mathrm{d}$ ) and significantly for $2 \mathrm{CO}_{2}$ and $6 \mathrm{CO}_{2}$, reaching $5 \mathrm{~mm}$ (mean rate $=$ $0.6 \mathrm{~mm} / \mathrm{d}$ ). For the NRA trial, 3 experts characterized the creamy underrind as runny.

After $13 \mathrm{~d}$ of ripening, the color of the cheeses manufactured under CRA conditions was white. Under all the 

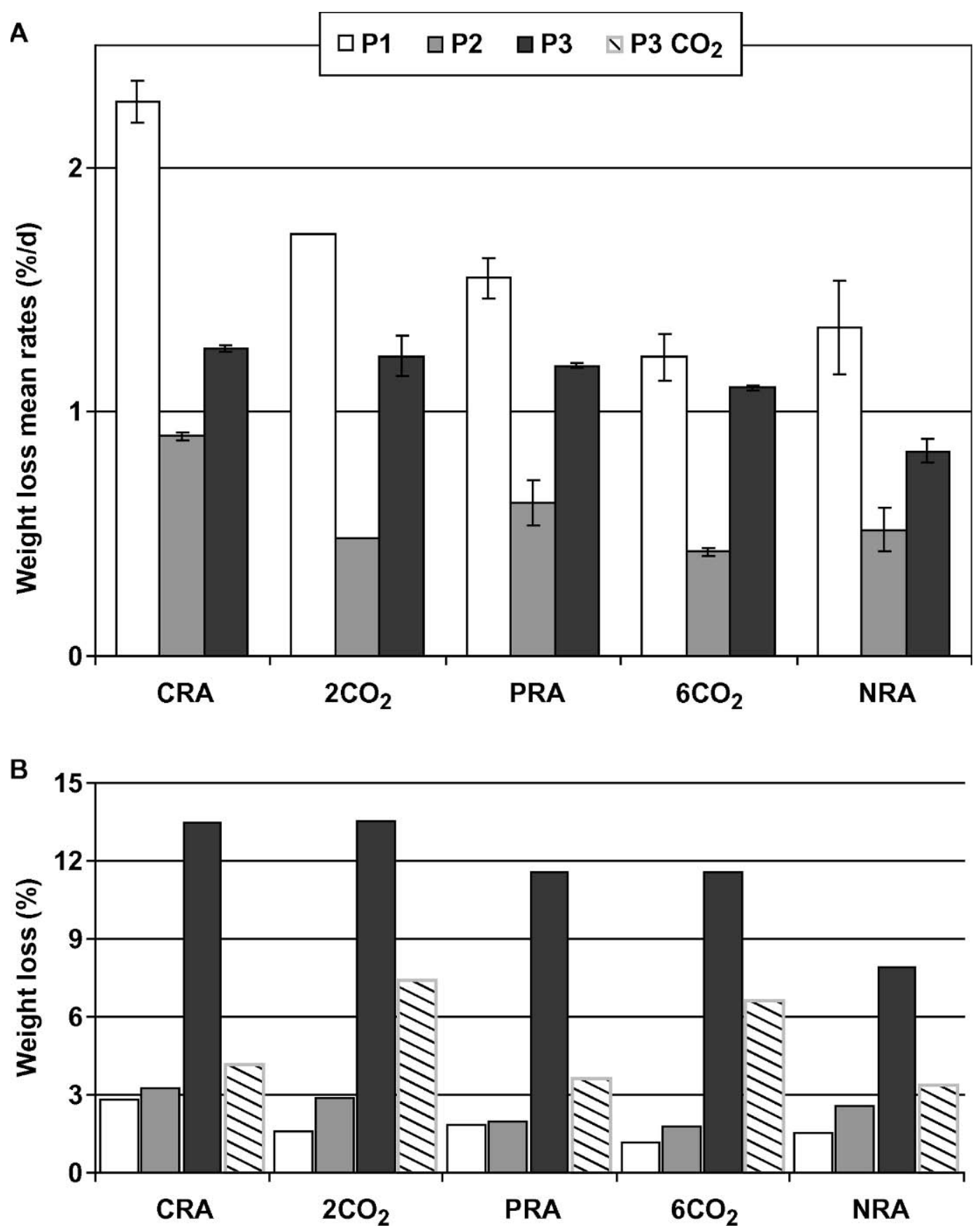

Figure 4. Mean rates (A) and percentage of weight losses (B) as a function of ripening phases (P1, P2, and P3) for different atmospheric conditions. $\mathrm{CRA}=$ continuously renewed atmosphere; $\mathrm{NRA}=$ no renewed atmosphere; $\mathrm{PRA}=$ periodically renewed atmosphere; $2 \mathrm{CO}_{2}, 6 \mathrm{CO}_{2}=$ regulation of $\mathrm{CO}_{2}$ concentration at 2 and $6 \%$, respectively. Three phases $(\mathrm{P} 1, \mathrm{P} 2$, and $\mathrm{P} 3)$ characterized the phenomena. $\mathrm{P} 3 \mathrm{CO}_{2}=$ percentage of weight loss by $\mathrm{CO}_{2}$ released during $\mathrm{P} 3$.

other atmospheric conditions, the cheeses were cream colored. Mycelium coated the entire cheese surface, and it was long for the trials without $\mathrm{CO}_{2}$ regulation (CRA, NRA) and was of medium length for the tests with regulated $\mathrm{CO}_{2}$.
The moisture on the rind was described as low for $\mathrm{CRA}, 2 \mathrm{CO}_{2}$, and PRA cheeses. For the cheeses manufactured under $6 \mathrm{CO}_{2}$ or NRA conditions, moisture was moderate or high, respectively. A similar difference of consistency was noted between NRA cheeses and the 


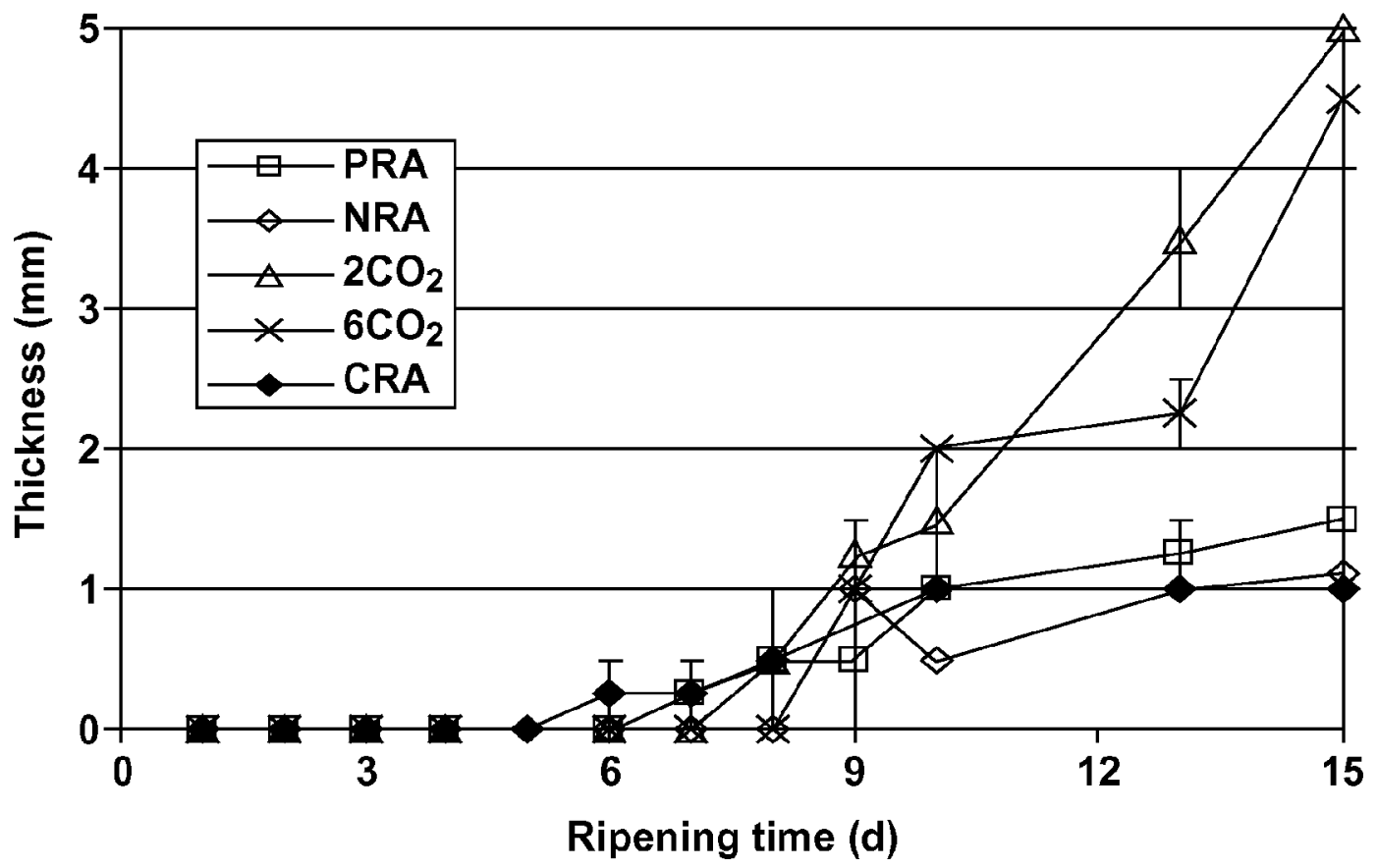

Figure 5. Increase of the creamy underrind thickness vs. ripening time for the different atmospheric compositions. CRA $=$ continuously renewed atmosphere; $\mathrm{NRA}=$ no renewed atmosphere; $\mathrm{PRA}=$ periodically renewed atmosphere; $2 \mathrm{CO}_{2}, 6 \mathrm{CO}_{2}=$ regulation of $\mathrm{CO}_{2}$ concentration at 2 and $6 \%$, respectively.

others. It was low for NRA and medium for the other conditions; NRA cheeses were also described as slightly sticky.

The general appearance of the cheeses was satisfactory for the CRA and $2 \mathrm{CO}_{2}$ tests. In the other trials $\left(6 \mathrm{CO}_{2}, \mathrm{PRA}\right.$, and NRA), the centers of the cheeses collapsed.

\section{DISCUSSION}

Changes in $\mathrm{O}_{2}$ and $\mathrm{CO}_{2}$ concentration during ripening, and their associated kinetics, have been linked to growth and respiratory activities of microorganisms involved in cheese ripening. Atmospheric compositions have also been linked to biological phenomena.Under CRA conditions, it was not possible to measure the $\mathrm{O}_{2}$ consumption and the $\mathrm{CO}_{2}$ release. The 2 phenomena were undetectable due to the new air supply (renewal rate $=2$ ). This supply induced a dilution of $\mathrm{CO}_{2}$ and an increase in $\mathrm{O}_{2}$ in the ripening chamber.

For all trials between $\mathrm{d} 1$ and 4 , there was no significant change in $\mathrm{O}_{2}$ and $\mathrm{CO}_{2}$ concentrations. During this period, $K$. lactis grew exponentially and mainly consumed lactose on the cheese rind (Leclercq-Perlat et al., 2004, 2006). Kluyveromyces lactis consumes lactose before starting lactate uptake (L. Soulignac, SOREDAB, La Boissiere école, France, unpublished results). Between $\mathrm{d} 3$ and 15, characterized by $\mathrm{O}_{2}$ consumption and $\mathrm{CO}_{2}$ production, growth of several species took place as described in the companion paper (LeclercqPerlat et al., 2006) for the same set of cheeses. Geotrichum candidum increased its concentration on the rind from d 2, consuming lactate, but never lactose. Penicillium camemberti sporulation growth started on $\mathrm{d} 5$ with an exponential phase up to $d 8$. These microorganisms deacidified the cheese rind by oxidizing the lactate produced by the lactic acid bacteria to $\mathrm{H}_{2} \mathrm{O}$ and $\mathrm{CO}_{2}$ as previously shown by Leclercq-Perlat et al. (2004). Growth of B. aurantiacum occurred after $9 \mathrm{~d}$ except for the trials with NRA conditions (under which this bacteria did not grow). The dynamics of proteolysis was correlated with growth of $G$. candidum, $P$. camemberti, and $B$. aurantiacum known for their proteolytic, peptidolytic, and lipolytic activities. These activities play an important role in the development of cheese texture (Lenoir, 1983; Leclercq-Perlat et al., 2004).

Under conditions of PRA and NRA, the maximum respiration rates (reached on $\mathrm{d} 6$ ) were not significantly different $\left(0.06 \mathrm{~mol} / \mathrm{m}^{2}\right.$ per $\left.\mathrm{h}\right)$. They were about $40 \%$ higher than those reported by Wolfseder et al. (1973) for Camembert cheese and by Roger et al. (1998) for $P$. camemberti in semisoft cheeses. This could be explained by differences in strains and cheese technology. Microorganisms are not specified in the study of Wolfseder et al. (1973), and Roger et al. (1998) only used one strain of $P$. camemberti. The total $\mathrm{O}_{2}$ consumption and $\mathrm{CO}_{2}$ 
production were slightly different between PRA and NRA trials. They were about $10 \%$ lower under NRA conditions because the respiration stopped after $11 \mathrm{~d}$.

Under atmospheric conditions with constant $\mathrm{CO}_{2}$ levels of 2 or $6 \%$, significant differences in respiration rates were found in comparison to the trials described immediately above. On d 6, under constant $\mathrm{CO}_{2}$ concentrations, the maximum rates were 70 to $100 \%$ higher than those observed when the $\mathrm{CO}_{2}$ dynamics were not controlled (CRA, NRA). Leclercq-Perlat et al. (2006) have shown that $G$. candidum growth was faster and more important when $\mathrm{CO}_{2}$ was present from the beginning of ripening. The oxidizing of lactate and the decarboxylation of amino acids derived from the proteolysis could well explain the increases in $\mathrm{CO}_{2}$ production. Geotrichum candidum and $P$. camemberti, which grow faster when $\mathrm{CO}_{2}$ level is $2 \%$, are well known for their proteolytic and peptidolytic activities (Lenoir, 1983; Boutrou and Guéguen, 2005). This confirmed increase is in agreement with Roger et al. (1998) who claimed that an initial $\mathrm{CO}_{2}$ concentration of $10 \%$ increases the respiration rate of $P$. camemberti.

Except in the NRA trials, the oxygen concentration of the ripening room never dropped under $12 \%$. At those levels, the growth of $P$. camemberti was not limited, as shown previously by Doyon et al. (1997). For G. candidum, an atmosphere composed of 1 to $3 \%$ of $\mathrm{O}_{2}$, with or without $\mathrm{CO}_{2}$, resulted in a biomass identical to that obtained in presence of air (Choisy et al., 2000). Thus, it could be concluded that $\mathrm{O}_{2}$ limitations had no significant effect on growth of $G$. candidum and $P$. camemberti under our experimental conditions. For NRA trials, during which the $\mathrm{O}_{2}$ concentration was lower than $5 \%$ after d 9, P. camemberti mycelia (visual appearance) stopped growing and $B$. aurantiacum did not grow at all.

Several factors affect weight losses during cheese ripening: airflow and relative humidity are key (Simal et al., 2001; Mirade et al., 2004). In our case, during the first 2 phases (P1 and P2) of the experiments, no respiration activity was detected. For a given temperature, $\mathrm{RH}$ (85 and 95\% for P1 and P2, respectively) directly influenced the rate of water evaporation of cheese rind with $\mathrm{a}_{\mathrm{w}}$ close to 1 . The higher the difference between $\mathrm{HR}$ and $\mathrm{a}_{\mathrm{w}}$, the higher are the water losses. The airflow also had an impact on weight loss. Under CRA conditions, air velocity was the highest, and losses were higher (Figure 4) than under the other atmospheric conditions carried out with zero (NRA) or almost zero $\left(2 \mathrm{CO}_{2}, 6 \mathrm{CO}_{2}, \mathrm{PRA}\right)$ airflow. For NRA tests (Figure 4), weight losses were not equal to zero even when there was no airflow. However, a study of the air velocity fields around the cheese and of the ventilation homogeneity in the pilot ripening room would be necessary to evaluate more precisely the effect of the flow rate. The air velocity measured around cheeses was less than $0.3 \mathrm{~m} / \mathrm{s}$ (P. S. Mirade, INRA, Theix, France, personal communication).

During P3, characterized by an important respiratory activity producing $\mathrm{CO}_{2}$ and $\mathrm{H}_{2} \mathrm{O}$, the differences between the trials were less important except for NRA, which remained at the lowest level (7.9\%). Weight losses were nearly similar for CRA and for $2 \mathrm{CO}_{2}(13.5 \%)$ as well as for PRA and for $6 \mathrm{CO}_{2}(11.6 \%$; Figure 4). Regulating $\mathrm{CO}_{2}$ concentration required more frequent air injection $\left(2 \mathrm{CO}_{2}, 6 \mathrm{CO}_{2}\right)$ and longer air injection (PRA). Thus, the airflow pattern was modified, and it could change the evaporation of water from surface to atmosphere.

The 3 sensory evaluators found that the cheeses with the most important weight losses (CRA, $2 \mathrm{CO}_{2}$, PRA; Figure 3) were also the driest. During P3, the weight loss was the sum of water evaporation and $\mathrm{CO}_{2}$ release. The main reasons for $\mathrm{CO}_{2}$ releases were the oxidation of the lactate and the decarboxylation of amino acids derived from proteolysis. The amount of released $\mathrm{CO}_{2}$ depended on the ripening atmospheric compositions (Figure 2, Table 1). The released $\mathrm{CO}_{2}$ represented 4.15, 3.62 , and $3.38 \%$ of total weight losses for CRA, PRA, and NRA trials, respectively, against 7.43 and $6.59 \%$ for $2 \mathrm{CO}_{2}$ or $6 \mathrm{CO}_{2}$ trials, respectively (Figure 4). For CRA trials, the released $\mathrm{CO}_{2}$ was estimated as the difference between measured weight loss and weight loss assigned to water. In P3, the water loss kinetic was considered constant and similar to those obtained during P2. It appeared that cheese respiratory activity could be modified if $\mathrm{CO}_{2}$ concentrations were regulated.

During ripening, proteolysis is one of the most important biological phenomena. In surface mold-ripened varieties, it affects cheese texture due to breakdown of the protein network, and contributes to the increase in pH (Sousa et al., 2001). In Camembert-type cheeses, the development of proteolytic activity of ripening microorganisms is considerably more extensive on the surface of cheese than in the core, where the enzymatic activity remains low. Noomen (1983) has shown that enzymes produced by microorganisms in the cheese rind never diffuse to the core. Therefore, the thickening of the creamy underrind from the surface to the core may be a good source of information about overall proteolysis of cheeses (Bonaïti et al., 2004). The thickness of the creamy underrind was negligible during the first 5 $\mathrm{d}$ of ripening. It was measurable on $\mathrm{d} 6$ and then increased until the end of ripening. Leclercq-Perlat et al. $(2004,2006)$ have shown that at this time 1) the growth of G. candidum was exponential, and 2) P. camemberti mycelium growth as well as $\mathrm{pH}$ and proteolysis indices (acid-soluble N and NPN) began to increase. Growth of G. candidum was faster and more important when $\mathrm{CO}_{2}$ 
was present; $P$. camemberti mycelium growth was higher at low levels of $\mathrm{CO}_{2}$.

In fact, for all trials, the overall changes in $\mathrm{CO}_{2}$ production (Figure 2, Table 1) and creamy underrind thickness (figure 5) were similar. The higher the $\mathrm{CO}_{2}$ production rate, the thicker was the creamy underrind. Levels of $\mathrm{CO}_{2}$ had an indirect effect on the thickening of the creamy underrind thickness.

The NRA trial was carried out under exceptional ripening conditions. Weight losses and thickness of the creamy underrind were low. However, the quality of the underrind was very poor. It was so runny that the experts evaluated it as lacking consistency. For $6 \mathrm{CO}_{2}$ and PRA trials, a collapse of the rind was observed. This result showed that when $\mathrm{CO}_{2}$ concentrations were too high they had negative effects on the overall quality of the cheeses.

In addition to the effect on growth and proteolysis, the presence of a high concentration of $\mathrm{CO}_{2}$ and its solubility could negatively modify the texture of the cheese. Olarte et al. (2001) explained the structural losses at high $\mathrm{CO}_{2}$ concentration by the high solubility of $\mathrm{CO}_{2}$ in the cheese aqueous phase.

\section{CONCLUSIONS}

This present study confirms the importance of relative humidity on weight losses of cheeses during ripening. The lower the relative humidity of the ripening room, the higher were the weight losses. Acting on this parameter could change ripening dynamics. In effect, changes in water losses affect water activity; consequently, growth and activity of microorganisms involved in ripening are affected. The airflow rate also affects the weight losses and the atmospheric composition. A study of the air velocity fields around the cheese would provide more precise information on its effects.

The composition of the atmosphere played a determining role in the respirations of ripening microorganisms and in cheese dynamics (water and $\mathrm{CO}_{2}$ losses, creamy underrind thickness, and appearance). In trials in which $\mathrm{CO}_{2}$ was initially injected at 2 or $6 \%$, respiration rate, $\mathrm{O}_{2}$ consumption, and $\mathrm{CO}_{2}$ production were higher and the evolution of proteolysis was faster and more significant. These results indicate that changes in the atmospheric conditions provide a convenient means of controlling ripening. To reduce time and cost, compared with optional technologies previously described (Law, 2001), modified atmospheres (gaseous composition, airflow) could be new technological options suitable for accelerating ripening.

However, the effect of the initial $\mathrm{CO}_{2}$ concentrations on cheese dynamics after wrapping is unknown and further investigation along these lines are necessary.

\section{ACKNOWLEDGMENTS}

The authors are deeply grateful to Suzette TanisPlant for her editorial advice. We would like to thank MENRT (Paris, France) and ARILAIT (Paris, France) for their financial support.

\section{REFERENCES}

Al-O Taibi, M. M., and A. Wilbey. 2004. Effect of temperature and salt on the maturation of white-salted cheese. Int. J. Dairy Technol. 57:57-63.

Blanc, B., J. O. Bosset, B. Martin, and J. Jimeno. 1983. Echanges gazeux à la surface de gruyère en cours de maturation. Schweiz. Milchw. Forsch. 12:30-34.

Bonaïti, C., M. N. Leclercq-Perlat, E. Latrille, and G. Corrieu. 2004 Deacidification by Debaryomyces hansenii of smear soft cheeses ripened under controlled conditions: Relative humidity and temperature influences. J. Dairy Sci. 87:3976-3988.

Boutrou, R., and M. Guéguen. 2005. Interests in Geotrichum candidum for cheese technology. Int. J. Food Microbiol. 102:1-20.

Choisy, C., M. Desmazeaud, M. Gueguen, J. Lenoir, J. L. Schmidt, and C. Tourneur. 2000. Cheese ripening: Microbial phenomena. Pages 377-440 in Cheesemaking. A. Eck and C. Gillis, ed. Tec Doc Lavoisier, Paris, France.

Doyon, G., J. Gagnon, D. Lafontaine, C. Desilets, and C. P. Champagne. 1997. The effect of carbon dioxide on the growth of Penicillium camemberti. Microbiol. Alim. Nutr. 15:291-297.

Feeney, E. P., P. F. Fox, and T. P. Guinee. 2001. Effect of ripening temperature on the quality of low moisture Mozzarella cheese: 1. Composition and proteolysis. Lait 81:463-474.

Guinee, T. P., E. P. Feeney, and P. F. Fox. 2001. Effect of ripening temperature on the quality of low moisture Mozzarella cheese: 2. Texture and functionality. Lait 81:475-485.

Kiermeier, F., and H. Wolfseder. 1972. Behaviour of packaged cheese: III. The influence of packaging on gas metabolism of Camembert. Z. Lebens. Unters. Forsch. 150:75-83.

Kujawski, M., G. Cichosz, E. Podhajna, and B. Sanko. 2003. Effect of ripening temperature on proteolysis and organoleptic properties of Edam-type cheese. Elec. J. Polish Agric. Univ., Food Science and Technology, 6(1).

Law, B. A. 2001. Controlled and accelerated cheese ripening: The research base for new technologies. Int. Dairy J. 11:383-398.

Leclercq-Perlat, M. N., D. Picque, H. Riahi, and G. Corrieu. 2006. Microbiological and biochemical aspects of Camembert-type cheeses depend on atmospheric composition in the ripening chamber. J. Dairy Sci. 89:3260-3273

Leclercq-Perlat, M. N., F. Buono, D. Lambert, E. Latrille, H. E. Spinnler, and G. Corrieu. 2004. Controlled production of Camemberttype cheeses. Part I: Microbiological and physicochemical evolutions. J. Dairy Res. 71:346-354.

Lenoir, J. 1983. The surface microflora and their actions during cheese ripening. Int. Dairy Fed. Bull. FIL-IDF 171:3-19.

Macedo, A. C., F. X. Malcata, and J. C. Oliviera. 1997. Effect of production factors and ripening conditions on the characteristics of Serra cheese. Int. J. Food Sci. Technol. 32:501-511.

Mirade, P. S., T. Rougier, A. Kondjoyan, D. Daudin, D. Picque, and G. Corrieu. 2004. Caractérisation expérimentale de l'aéraulique d'un hâloir de fromagerie et des échanges air-produit. Lait 84:483-500.

Noomen, A. 1983. The role of the surface flora in the softening of cheeses with a low initial pH. Neth. Milk Dairy J. 82:891-899.

Olarte, C., E. Gonzales-Fandos, and S. Sanz. 2001. A proposed methodology to determine the sensory quality of a fresh goat's cheese (Cameros cheese): Application to cheeses packaged under modified atmospheres. Food Qual. Pref. 12:163-170.

Perrot, N., L. Agioux, I. Ioannou, G. Mauris, G. Corrieu, and G. Trystram. 2004. Decision support system design using the opera- 
tor skill to control ripening - Application of fuzzy symbolic approach. J. Food Eng. 64:321-333.

Ramet, J. P. 1997. Technologie comparée de l'affinage de différents types de fromage. Pages 447-474 in Le Fromage. A. Eck and C. Gillis, ed. Tec Doc Lavoisier, Paris, France.

Roger, B., S. Desobry, and J. Hardy. 1998. Respiration of Penicillium camemberti during ripening and cold storage of semi-soft cheese. Lait 78:241-250.

Simal, S., E. S. Sanchez, J. Bon, A. Femenia, and C. Rossello. 2001 Water and salt diffusion during cheese ripening: Effect of the external and internal resistances to mass transfer. J. Food Eng. $48: 269-275$.
Sousa, M. J., Y. Ardö, and P. L. H. McSweeney. 2001. Advances in the study of proteolysis during cheese ripening. Int. Dairy J. 11:327-345.

Vassal, L., and J. C. Gripon. 1984. L'amertume des fromages à pâte molle de type Camembert: Rôle de la présure et de Penicillium caseicolum, moyens de la contrôler. Lait 64:397-417.

Weissenfluh, A., and Z. Puhan. 1987. The influence of the climatic conditions on the growth of Penicillium camemberti and the quality of Camembert cheese. Schweiz. Milchw. Forschung. 16:37-44.

Wolfseder, V. H. 1973. Determination of gas exchange in Camembert cheese by means of physical gas analyzers. Milchwissenschaft 28:418-423. 